\title{
Isolasi dan Karakterisasi Gen Pto Asal 20 Aksesi Anggrek Phalaenopsis
}

\section{Isolation and Characterization of Pto Gene from 20 Phalaenopsis Orchid Genotypes}

\author{
Juanita Elina ${ }^{1}$, Dewi Sukma ${ }^{2}$, Giyanto ${ }^{3}$, dan Sudarsono ${ }^{2 *}$ \\ 'Program Studi Pemuliaan dan Bioteknologi Tanaman, Sekolah Pascasarjana, Institut Pertanian Bogor \\ ${ }^{2}$ Departemen Agronomi dan Hortikultura, Fakultas Pertanian, Institut Pertanian Bogor \\ (Bogor Agricultural University), Jl. Meranti, Kampus IPB Darmaga, Bogor 16680, Indonesia \\ ${ }^{3}$ Departemen Proteksi Tanaman, Fakultas Pertanian, Institut Pertanian Bogor \\ (Bogor Agricultural University), Jl. Meranti, Kampus IPB Darmaga, Bogor 16680, Indonesia
}

Diterima 13 Oktober 2016/Disetujui 11 April 2017

\begin{abstract}
Bacterial soft rot disease because of Dickeya sp. infection is the main problem in Phalaenopsis production in Indonesia, but the percentage of infected plants has never been recorded in detail. Isolation and characterization of Pto gene from Phalaenopsis could be useful to support breeding for resistance Phalaenopsis. Encoding serine-threonine kinase, Pto gene confers resistance to bacterial infection of Pseudomonas syringae in tomato. The objectives of this study were to isolate, sequence and characterize fragment of Pto gene from 20 genotypes of Phalaenopsis (16 species and 4 hybrids) and to evaluate their molecular diversity. Genomic fragments of Phalaenopsis were amplified using Pto specific degenerate primers; and the PCR amplicons were sequenced. Searching the identity of determined sequences was done using BLAST against all accessions in NCBI GenBank DNA database and in Conserve Domain Database. PCR amplification using Pto specific primers produced a single DNA fragment of $\sim 500 \mathrm{bp}$. The determined nucleotide sequences from the amplicon were $\sim 449$ $\mathrm{bp}$. The nucleotide sequences of the amplicons from 20 Phalaenopsis genotypes showed high sequence identity to Pto from Musa acuminata. Translation of the amplicon results in $\sim 149$ amino acid residues. Comparison of the translated polypeptides identify indicated there were low variations of Pto gene among accessions since they contain the PTO catalytic domain and the Serine/Threonine kinases, sub family of Interleukin-1 Receptor Associated Kinase (STK_IRAK) which are the conserved domains for PTO.
\end{abstract}

Keywords: catalytic domain, disease resistance, fragment Pto gene, phylogenetic, $R G A$

\section{ABSTRAK}

Masalah utama dalam budidaya Phalaenopsis di Indonesia adalah penyakit busuk lunak yang disebabkan oleh infeksi Dickeya sp, namun persentase tanaman yang terserang di Indonesia belum pernah didata secara mendetail. Isolasi dan karakterisasi gen Pto dari anggrek Phalaenopsis diharapkan bermanfaat bagi pengembangan program pemuliaan anggrek Phalaenopsis khususnya ketahanan terhadap penyakit. Gen Pto dikenal sebagai gen penyandi serine-threonine kinase yang memberikan ketahanan pada tomat terhadap infeksi bakteri Pseudomonas syringae. Tujuan penelitian ini adalah mengisolasi dan mengkarakterisasi fragmen gen Pto dari 20 anggrek Phalaenopsis (16 spesies dan 4 hibrida) sehingga diperoleh keragaman molekuler gen Pto untuk mengidentifikasi anggrek Phalaenopsis tahan. Fragmen gen Pto diamplifikasi menggunakan primer spesifik Pto dilanjutkan dengan sekuensing. Identitas sekuen diperoleh dengan menggunakan BLAST terhadap semua aksesi yang terdeposit di NCBI GenBank DNA database dan conserve domain database. Hasil amplifikasi PCR menggunakan primer spesifik Pto menghasilkan produk $\sim 500 \mathrm{pb}$. Berdasarkan runutan nukleotida, fragmen DNA yang teramplifikasi sepanjang $\sim 449$ pb. Runutan nukleotida dari fragmen DNA asal 20 aksesi Phalaenopsis menunjukkan kesamaan identitas yang tinggi dengan gen Pto Musa acuminata. Translasi amplikon asal Phalaenopsis menyandikan 149 asam amino. Analisis pensejajaran asam amino menunjukkan terdapat keragaman yang rendah dari protein PTO antar genotipe Phalaenopsis dan amplikon merupakan bagian dari domain katalitik PTO, yaitu domain serine/threonine kinase sub-famili Interleukin-1 Receptor Associated Kinases (STK_IRAK).

Kata kunci: domain katalitik, filogenetik, fragmen gen Pto, ketahanan penyakit, RGA

* Penulis untuk korespondensi. e-mail: s_sudarsono@ymail.com 


\section{PENDAHULUAN}

Phalaenopsis merupakan salah satu jenis anggrek yang paling digemari dan banyak dikembangkan masyarakat. Anggrek ini memiliki keunggulan warna bunga yang beragam, bentuk bunga yang unik dan vase life yang panjang. Dalam pengembangan dan budidaya anggrek Phalaenopsis sering ditemukan serangan penyakit busuk lunak akibat infeksi bakteri Dickeya dadantii (sinonim dari Erwinia chrysanthemi [Toth et al., 2011]), namun persentase tanaman yang terserang di Indonesia belum pernah didata secara mendetail. Salah satu alternatif cara pengendalian penyakit yang efektif adalah dengan menggunakan varietas resisten terhadap infeksi patogen penyebabnya (Yusnita et al., 2005).

Keberadaan aksesi yang resisten sangat bermanfaat dalam pemuliaan tanaman Phalaenopsis karena dapat digunakan sebagai donor sifat resisten (Fu dan Huang, 2011). Evaluasi keragaman respon ketahanan tanaman terhadap penyakit (resistensi) dapat dilakukan secara langsung dengan inokulasi tanamannya menggunakan isolat patogen yang diuji (Zainal et al., 2011; Sutanto et al., 2014) atau dengan mengevaluasi keragaman gen ketahanan ( $R$ gene atau resistance gene analog) yang ada pada genom tanamannya (Quirin et al., 2012).

Produk protein dari gen ketahanan ( $R$ gene) memiliki kemampuan untuk mendeteksi awal terjadinya infeksi dan mengaktifkan mekanisme ketahanan tanaman terhadap infeksi patogen (Han et al., 2011). Tanaman mampu mendeteksi awal infeksi melalui interaksi spesifik antara protein yang disandi oleh gen ketahanan ( $R$ gene) dengan faktor avirulen (avr factor) yang dihasilkan oleh patogen (Rose et al., 2007).

Gen ketahanan ( $R$ gene) dikelompokkan menjadi delapan kelas berdasarkan motif domain terkonservasi pada polipeptidanya (Zhai et al., 2014). Sejumlah 91 gen ketahanan asal tanaman telah berhasil diisolasi dan dikarakterisasi (Gurunani et al., 2012), baik dari tanaman dikotil ataupun monokotil (Meyers et al., 2005). Sebagian besar polipeptida yang disandi oleh gen resisten tersebut mempunyai domain terkonservasi nuclear binding site leucine rich repeat (NBS - LRR [Quirin et al., 2012]). Gen Pto merupakan salah satu kelompok gen ketahanan yang tidak mempunyai domain terkonservasi NBS-LRR tetapi tergolong sebagai gen ketahanan enzimatik (enzymatic $R$ gene [Gurunani et al., 2012]).

Gen Pto merupakan salah satu anggota kelompok resistance gene analog (RGA) yang produk proteinnya berperanan dalam pengenalan awal terjadinya infeksi dan proses transduksi sinyal terjadinya infeksi untuk mengaktifkan mekanisme respon ketahanan tanaman (Wan et al., 2009). Isolasi dan karakterisasi domain terkonservasi dari gen Pto telah berhasil dilakukan untuk kakao ( $\sim 540$ pb, Kurniasih, 2012), pisang ( $\sim 550$ pb, Peraza-Echeverria et al., 2007) dan sejumlah tanaman lainnya. Domain terkonservasi pada produk protein PTO berupa kinase serintreonin (Serine-Threonin Kinase), berfungsi sebagai enzim yang dapat melakukan fosforilasi protein kinase tertentu
(Castells dan Casacuberta, 2007) dan meneruskan sinyal awal infeksi ke nukleus untuk aktifasi mekanisme resistensi terhadap infeksi patogen. Wan et al. (2013) menyatakan bahwa Pto mengkode serine/threonine kinase yang menjadi perantara ketahanan tanaman tomat terhadap infeksi isolat bakteri Pseudomonas syringae pv. tomato dengan faktor avirulensi avrPto. Keberadaan gen penyandi serine/ threonine kinase diharapkan dapat menghambat penyebaran busuk lunak akibat infeksi Dickeya dadantii pada anggrek Phalaenopsis.

Meskipun telah diisolasi dan dikarakterisasi dari berbagai tanaman, informasi tentang keberadaan gen Pto pada Phalaenopsis, isolasi dan karakterisasinya belum dilaporkan. Tersedianya informasi tentang gen Pto asal Phalaenopsis dan keragaman molekulernya dapat digunakan untuk identifikasi ketahanan Phalaenopsis terhadap infeksi $D$. dadantii, patogen penyebab busuk lunak pada Phalaenopsis di Indonesia (Sudarsono et al., 2017; Sukma et al., 2017). Penelitian yang dilakukan bertujuan untuk (1) mengisolasi fragmen gen Pto dengan amplifikasi PCR, (2) mengkarakterisasi fragmen DNA yang teramplifikasi dengan DNA sequencing, dan (3) mempelajari keragaman residu asam amino yang ditranslasikan dari fragmen gen Pto asal Phalaenopsis. Informasi tentang karakter Pto asal Phalaenopsis dan keragaman residu asam amino yang diperoleh sangat berguna dalam pengembangan marka molekuler untuk sifat ketahanan Phalaenopsis terhadap serangan patogen yang kemudian akan digunakan dalam perakitan varietas tahan.

\section{BAHAN DAN METODE}

\section{Isolasi DNA Total dari 20 Aksesi Phalaenopsis}

Penelitian dilaksanakan mulai tahun 2014 sampai dengan 2015 di Laboratorium Biologi Molekuler Tanaman (PMB Lab.), Departemen Agronomi dan Hortikultura, Fakultas Pertanian, Institut Pertanian Bogor. Total DNA tanaman diisolasi menggunakan metode CTAB yang dimodifikasi (Sudarsono et al., 2017; Handini, 2014; Sutanto et al., 2014). Bahan tanaman yang digunakan adalah daun muda 20 aksesi anggrek Phalaenopsis. Contoh daun muda (0.3-0.4 g) digerus dengan larutan penyangga-lisis $(700 \mathrm{~mL})$ serta penambahan PVP $(0.007 \mathrm{~g})$. Hasil gerusan jaringan diinkubasi dalam waterbath pada suhu $65{ }^{\circ} \mathrm{C}$ selama 60 menit. Campuran diendapkan dengan sentrifugasi menggunakan WEALTEC E-Centrifuge kecepatan 6000 rpm selama 30 menit. Supernatan dipindahkan ke tabung eppendorf baru dan ke dalamnya ditambahkan kloroform: isoamil-alkohol (24:1) sebanyak volume supernatan. Setelah dicampur perlahan dan merata selama 3 menit, contoh disentrifugasi dengan kecepatan 6000 rpm selama 30 menit. Setelah sentrifugasi, supernatannya dipindahkan ke tabung yang baru. Ke dalam tabung Eppendorf ditambahkan sodium asetat $(0.1 \mathrm{x}$ volume supernatan $)$ dan isopropanol dingin ( $2 \mathrm{x}$ volume total supernatan). Setelah dicampur perlahan selama 3 menit, suspensi disentrifugasi dengan kecepatan 6000 rpm selama 30 menit hingga diperoleh endapan DNA. 
Endapan DNA dibilas dengan $100 \mu \mathrm{L}$ etanol dingin (70\%), disentrifugasi dan dikeringkan. Endapan DNA yang telah kering disuspensikan dalam $100 \mu \mathrm{L}$ aquabidest.

\section{Amplifikasi PCR dengan Primer Spesifik Pto}

Pasangan primer degenerate spesifik Pto yang digunakan terdiri atas primer forward (PtoF: 5'ggaggatttggtaargtntayaar-3') dan reverse (PtoR: 5'accacaccaaatgartanacrtc-3'). Amplifikasi PCR dilakukan menggunakan PtoF dan PtoR serta templat total DNA dari 20 aksesi Phalaenopsis. Setiap reaksi amplifikasi PCR dilakukan dengan menggunakan $4 \mu \mathrm{L}$ suspensi DNA, 0.75 $\mu \mathrm{L}(10 \mu \mathrm{M})$ masing-masing primer, 12.5 PCR Ready Mix (KAPA Biosystem), dan $7 \mu \mathrm{L} \mathrm{ddH_{2 }}$ O. Tahapan amplifikasi dilakukan sebagai berikut: denaturasi awal pada suhu $95^{\circ} \mathrm{C}$ selama 3 menit, diikuti dengan 35 siklus amplifikasi yang masing-masing siklus terdiri atas denaturasi pada 95 ${ }^{\circ} \mathrm{C}$ selama 10 detik, penempelan primer dengan temperatur $45.9^{\circ} \mathrm{C}$ selama 15 detik, dan pemanjangan primer pada suhu $72{ }^{\circ} \mathrm{C}$ selama 1 detik, serta diakhiri dengan pemanjangan primer pada suhu $72{ }^{\circ} \mathrm{C}$ selama 10 menit sesuai rekomendasi kit PCR KAPA Biosystem. Amplikon dievaluasi dengan elektroforesis gel agarose (1\%) menggunakan buffer SB 1x dan diwarnai dengan GelRed ${ }^{\mathrm{TM}}$ (Biotium Inc.). Visualisasi amplikon dilakukan dengan UV transilluminator dan elektroforegram di foto menggunakan kamera digital.

\section{Penentuan Runutan Nukleotida Amplikon}

Amplikon berupa pita tunggal dari masing-masing aksesi Phalaenopsis dikirim ke perusahaan penyedia layanan DNA sequencing (BASE-Asia, Malaysia) untuk proses penentuan runutan nukleotida. Penentuan runutan nukleotida menggunakan BigDye terminator sequencing kit (Applied Biosystems) dan produk sequencing dipisahkan dengan ABI 3730 automatic sequencer (Applied Biosystems).

Runutan basa nukleotida hasil amplifikasi PCR dianalisis menggunakan program Geneious Basic 5.6.6 (Biomatters, USA) untuk menentukan keberadaan primer PtoF dan PtoR yang digunakan di ujung-ujung amplikon. Runutan nukleotida amplikon dan runutan asam amino hasil translasi dari amplikon dibandingkan dengan semua aksesi yang tersedia di NCBI GenBank DNA Database menggunakan basic local allignment search tool (BLAST, http://blast.ncbi.nlm.nih.gov/blast.cgi). Hasil BLAST digunakan untuk menduga secara umum identitas amplikon yang didapatkan.

\section{Penentuan Identitas Amplikon}

Protein PTO diketahui mempunyai domain katalitik dengan runutan asam amino yang terkonservasi (Oh dan Martin, 2011). Keberadaan domain katalitik PTO pada hasil translasi dari amplikon dapat menjadi indikator bahwa amplikon tersebut merupakan bagian dari gen Pto. Untuk memastikan identitas amplikon, keberadaan domain katalitik PTO dievaluasi dengan data yang tersedia di di NCBI Conserved Domain Database (ncbi.nlm.nih.gov/
Structure/cdd/wrpsb.cgi). Hasil positif analisis keberadaan domain katalitik PTO mengindikasikan bahwa amplikon yang didapat merupakan bagian dari gen Pto.

Protein PTO merupakan salah satu anggota dari serine-threonine kinase protein super family, yang diketahui mempunyai conserved domain (CD) dengan runutan asam amino tertentu (Singh et al., 2012). Keberadaan CD pada hasil translasi amplikon dapat digunakan untuk mengkonfirmasi bahwa amplikon yang dievaluasi merupakan bagian dari gen Pto. Untuk itu, translasi dari amplikon dievaluasi kesamaannya dengan $\mathrm{CD}$ yang tersedia di database Conserved Domain NCBI (ncbi.nlm.nih.gov/ Structure/cdd/wrpsb.cgi). Hasil positif analisis keberadaan CD memastikan identitas amplikon sebagai bagian dari gen Pto.

\section{Filogenetika Polipeptida Hasil Translasi dari Amplikon Asal Phalaenopsis}

Analisis filogenetik runutan asam amino hasil translasi dari amplikon dilakukan untuk mengevaluasi hubungan kekerabatan antara amplikon dengan aksesi lain dari NCBI GenBank database. Runutan asam amino hasil translasi yang diperoleh dibandingkan dengan runutan asam amino gen Pto dari Musa acuminata (AAM97914.1), Triticum aestivum (AAL51075.1), Arachis hypogaea (AFB69787.1), Capsicum chinense (AAQ82660.1), Nicotiana repanda (ACO25565.1), danLycopersiconesculentum(AF220603.1). Konstruksi pohon filogenetika dibangun menggunakan metode Neighbour-Joining (NJ) dengan bantuan perangkat lunak MEGA versi 5 (Tamura et al., 2011). Nilai bootstrap berdasarkan 1000 kali pengulangan digunakan untuk menguji keakuratan data.

\section{HASIL DAN PEMBAHASAN}

\section{Amplifikasi PCR dengan Primer Spesifik Pto}

Disain pasangan primer degenerate spesifik Pto (PtoF dan PtoR) dilakukan berdasarkan sejumlah aksesi gen Pto dan posisi relatif primer terhadap PTO asal tomat dapat dilihat pada Gambar 1.A. Primer PtoF dimulai dari kodon penyandi asam amino ke-65 dan PtoR berakhir pada kodon penyandi asam amino ke-210 dari PTO tomat. Berdasarkan hal tersebut, amplikon yang diharapkan didapat sepanjang $\sim 440 \mathrm{pb}$.

Dari 20 aksesi Phalaenopsis yang dievaluasi, PCR dengan PtoF dan PtoR menghasilkan amplikon 500 pb (Gambar 1B). Setelah DNA sequencing seluruh fragmen amplikon, berhasil diidentifikasi runutan nukleotida sebanyak antara 423-449 pb. Sequencing langsung dilakukan terhadap produk PCR, sehingga sejumlah nukleotida di bagian ujung 5' ataupun ujung 3' tidak dapat ditentukan karena rendahnya kualitas identitas runutan DNA yang didapat. Dengan demikian, terdapat perbedaan panjang (51$77 \mathrm{pb}$ ) antara ukuran fragmen masing-masing amplikon dengan total runutan nukleotida yang teridentifikasi.

Primer degenerate spesifik Pto telah digunakan untuk mengamplifikasi bagian gen Pto dan menghasilkan 
amplikon sepanjang 540 pb untuk kakao (Kurniasih, 2012) serta $\sim 550 \mathrm{pb}$ untuk karet (Zhai et al., 2014). Amplikon dari kakao dan karet tersebut merupakan bagian dari total open reading frame (ORF, 963 pb) gen Pto (Orsi et al., 2011).

\section{Runutan Nukleotida Hasil Amplifikasi PCR}

DNA sequencing amplikon untuk 20 aksesi Phalaenopsis menghasilkan 38 runutan nukleotida yang berbeda dan teridentifikasi terdiri atas 423-449 pb (salah satu contohnya disajikan pada Gambar 1C). Dibandingkan dengan gen Pto asal tomat (AF220603.1), amplikon asal Phalaenopsis mengalami insersi 9 basa nukleotida pada posisi 265 dan delesi satu basa pada posisi 442. Translasi amplikon asal Phalaenopsis menyandikan 149 asam amino, tanpa intron dan stop kodon (Gambar 1C).

Analisis BLAST dengan semua aksesi di pangkalan data GenBank NCBI menunjukkan bahwa runutan asam amino yang ditranslasikan dari amplikon asal Phalaenopsis memiliki tingkat identitas yang tinggi (88-95\%) dengan protein PTO (Tabel 1), antara lain dari: Musa acuminata (identitas 95\%, AAM97914.1), Capsicum chinensis (89\%, AAQ82660.1), Nicotiana repanda (89\%, ACO25565.1) dan Arachis hypogaea (88\%, AFB69787.1), sehingga amplikon tersebut diduga merupakan fragmen gen Pto. Runutan nukleotida amplikon asal Phalaenopsis (38 aksesi) yang teridentifikasi telah disimpan di pangkalan data GenBank
NCBI dengan nomor aksesi KR184099-KR184118 dan KR259359-KR259376.

\section{Identitas Amplikon Asal Phalaenopsis}

Domain katalitik merupakan bagian terkonservasi pada semua protein PTO (Oh dan Martin, 2011) sehingga dapat digunakan untuk memastikan identitas amplikon asal Phalaenopsis. Polipeptida hasil translasi dari amplikon asal Phalaenopsis merupakan bagian dari domain katalitik PTO (Gambar 2A), yaitu pada posisi nukleotida ke-192-632 (residu asam amino ke-65-210) jika dibandingkan dengan PTO tomat. Bagian tersebut mempunyai kesamaan identitas yang tinggi dengan domain serine threonine kinase sub-famili Serine/Threonine kinases, Interleukin-1 Receptor Associated Kinases (STK_IRAK) yang merupakan bagian dari domain katalitik PTO (Gambar 2A). Hal ini mengindikasikan bahwa amplikon asal Phalaenopsis memang benar merupakan bagian dari gen Pto. Protein PTO memiliki domain katalitik protein kinase yang berperan penting dalam aktivasi respons ketahanan terhadap patogen bakteri (Lehti-Shiu dan Shiu, 2012). Pada domain katalitik PTO terdapat situs aktif enzim kinase (Castells dan Casacuberta, 2007) tipe serine/ threonine kinase (Afzal et al., 2008).

Analisis pensejajaran runutan asam amino hasil translasi amplikon Phalaenopsis dengan runutan domain katalitik PTO asal M. acuminata, T. aestivum dan domain
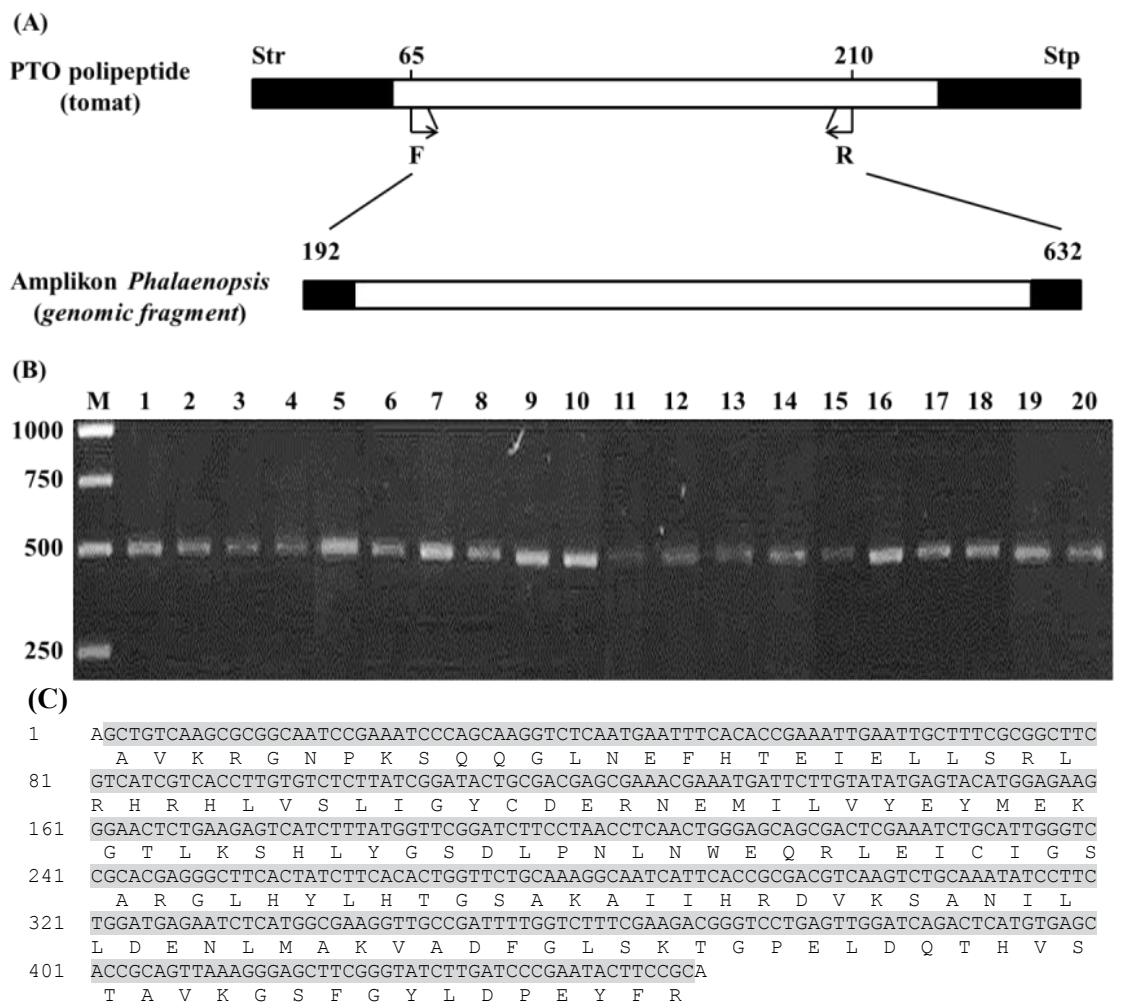

Gambar 1. (A) Diagram representasi protein yang disandi oleh gen Pto tomat Lycopersicon esculentum (aksesi AF220603.1, NCBI, 2003) dan posisi amplikon hasil PCR dengan primer spesifik Pto dan templat total DNA Phalaenopsis (NCBI, 2003). (B) Elektroforegram amplikon Phalaenopsis (genomic fragment) menggunakan sepasang primer spesifik Pto. (C) Runutan nukleotida dan hasil translasi amplikon Phalaenopsis schilleriana. Nukleotida yang diarsir merupakan bagian dari catalytic domain PTO. Str: Asam amino metionin. Stp: posisi kodon stop. Posisi primer $\mathrm{F}=$ forward, $\mathrm{R}=$ reverse, $\mathrm{pb}=$ pasang basa. Kolom 1-20: 20 aksesi anggrek Phalaenopsis; $\mathrm{M}=$ marka DNA (1 kb ladder) 
Tabel 1. Sequence identity antara runutan asam amino dari fragmen DNA hasil PCR asal Phalaenopsis bellina dengan fragmen Pto aksesi lain pada data GenBank

\begin{tabular}{llccc}
\hline $\begin{array}{l}\text { Aksesi } \\
\text { GenBank }\end{array}$ & \multicolumn{1}{c}{ Deskripsi aksesi } & $\begin{array}{c}\text { Query } \\
\text { coverage (\%) }\end{array}$ & Nilai E & $\begin{array}{c}\text { Identity } \\
(\%)\end{array}$ \\
\hline AAM97914.1 & Pto-like serine/threonine kinase (Musa acuminata) & 100 & $2.00 \mathrm{E}-99$ & 95 \\
ACO25565.1 & Protein kinase-coding resistance protein (Nicotiana repanda) & 100 & $3.00 \mathrm{E}-93$ & 89 \\
AAQ82660.1 & Pto-like serine/threonine kinase (Capsicum chinense) & 100 & $10.00 \mathrm{E}-94$ & 89 \\
AFB69787.1 & Pto-like receptor kinase resistance protein (Arachis hypogaea) & 100 & $2.00 \mathrm{E}-94$ & 88 \\
\hline
\end{tabular}

terkonservasi STK_IRAK (cd14066) juga menunjukkan identitas yang tinggi dan adanya situs aktif yang sama (Gambar 2B). Situs aktif sebagai bagian dari domain katalitik PTO diawali dengan motif residu asam amino DFG dan diakhiri motif PE, kedua motif tersebut dipisahkan oleh 25 residu asam amino (Gambar 2B). Pada situs aktif juga ditemukan domain $P+1$ loop yang ada di ujung akhir dari domain aktivasi (Gambar 2B). Residu asam amino terkonservasi, yang merupakan ciri domain katalitik PTO, terdiri atas asam amino threonine $(\mathrm{T})$, serine $(\mathrm{S})$ dan situs
$\mathrm{P}+1$ loop internal (G[S/T][F/L]GY[L/I]DPE) sama-sama ditemukan pada hasil translasi amplikon asal Phalaenopsis, PTO asal M. acuminata, T. aestivum, dan CDD14066 (Gambar 2B). Hasil ini mengkonfirmasi identitas amplikon asal Phalaenopsis yang didapatkan menggunakan primer PtoF dan PtoR adalah bagian gen Pto, salah satu gen ketahanan yang ada dalam genom Phalaenopsis.

Residu asam amino $\mathrm{S}$ dan $\mathrm{T}$ merupakan situs autofosforilasi, sedangkan $P+1$ loop merupakan domain yang berasosiasi dengan AvrPto (Zhai et al., 2014). Parravicini

(A)

\begin{tabular}{lrr}
$\begin{array}{c}\text { PTO polipeptide } \\
\text { (tomat) }\end{array}$ & 47 & 309 \\
\cline { 2 - 3 } & Catalytic Domain Pto & \\
\hline
\end{tabular}

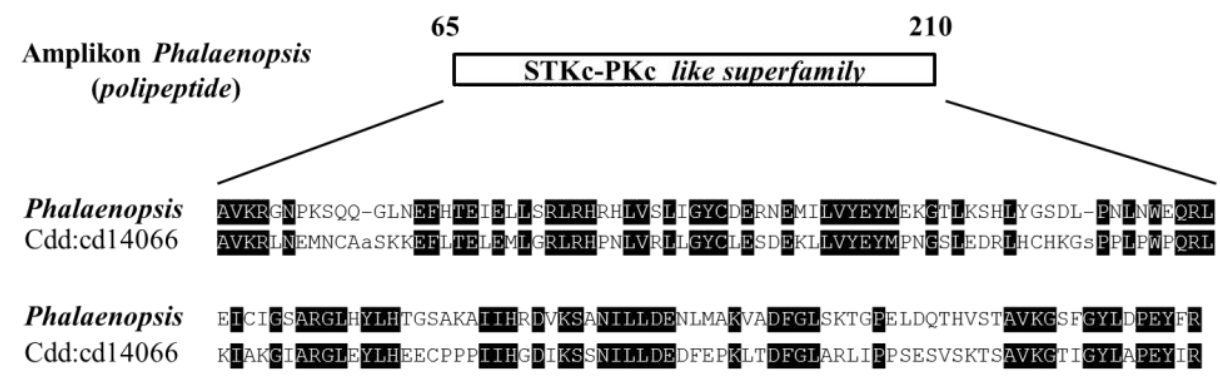

(B)

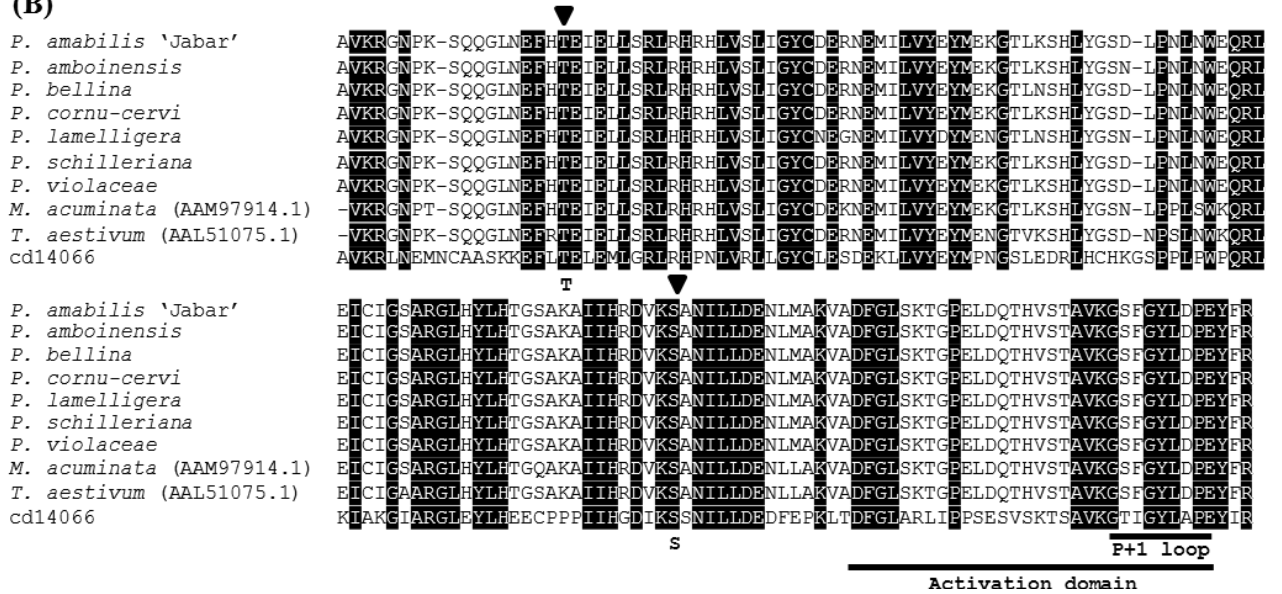

Gambar 2. Posisi relatif antara polipeptida yang ditranslasi dari amplikon asal Phalaenopsis dengan catalytic domain (cd) protein PTO (cd14066) (Marchler-Bauer et al., 2017). (A) Representasi catalytic domain (cd) protein PTO, posisi relatif polipeptida yang ditranslasi dari amplikon asal Phalaenopsis dan kesamaan residu asam aminonya dengan cd PTO. (B) Pensejajaran runutan asam amino polipeptida yang ditranslasi dari amplikon asal Phalaenopsis dengan conserve domain STKc-PKc (Serine) Threonine Kinase - Protein Kinase catalytic). AAM97914.1, AAL51075.1 merupakan aksesi PTO yang berasal dari NCBI DNA database dan cd14066 = bagian terkonservasi dari domain katalitik protein kinase. Residu asam amino aktif ditandai dengan segitiga hitam 
et al. (2011) menambahkan ketika $P+1$ loop berinteraksi dengan AvrPto maka resisdu asam amino serine/threonine mengalami autofosforilasi dan menyebabkan terjadinya transduksi sinyal untuk mengaktifkan mekanisme resistensi tanaman.

Analisis Filogenetika Runutan Asam Amino Amplikon Asal Phalaenopsis

Analisis filogenetik berdasarkan seluruh residu asam amino yang ditranslasikan dari amplikon, mengindikasikan adanya keragaman residu asam amino yang rendah dari gen Pto antar genotipe Phalaenopsis (Gambar 3.A).

(A)

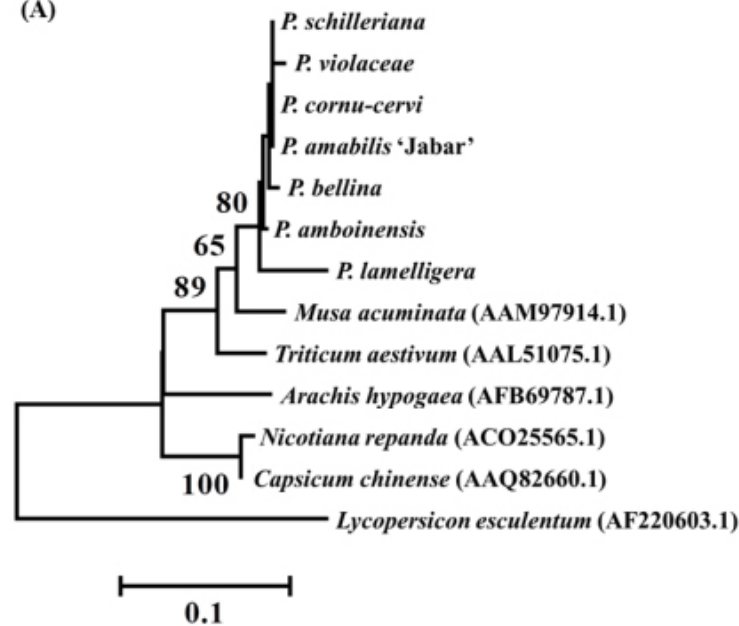

Berdasarkan seluruh residu asam amino yang ditranslasikan dari amplikon dan berdasarkan catalytic domain PTO-nya, PTO asal Phalaenopsis diduga memiliki progenitor yang sama dengan PTO asal M. Acuminata, T. aestivum, Arachis hypogaea, Capsicum chinensis dan Nicotiana repanda (Gambar 3.A dan 3.B). Sebaliknya, PTO asal Phalaenopsis diduga memiliki progenitor yang berbeda dengan PTO asal tomat (Gambar 3.A dan 3.B). Sebaliknya, PTO asal Phalaenopsis diduga memiliki progenitor yang berbeda dengan PTO asal tomat (Gambar 3.A dan 3.B). Pada Gambar 4 disajikan keragaman karakteristik bunga dari 20 aksesi anggrek Phalaenopsis yang digunakan dalam penelitian.

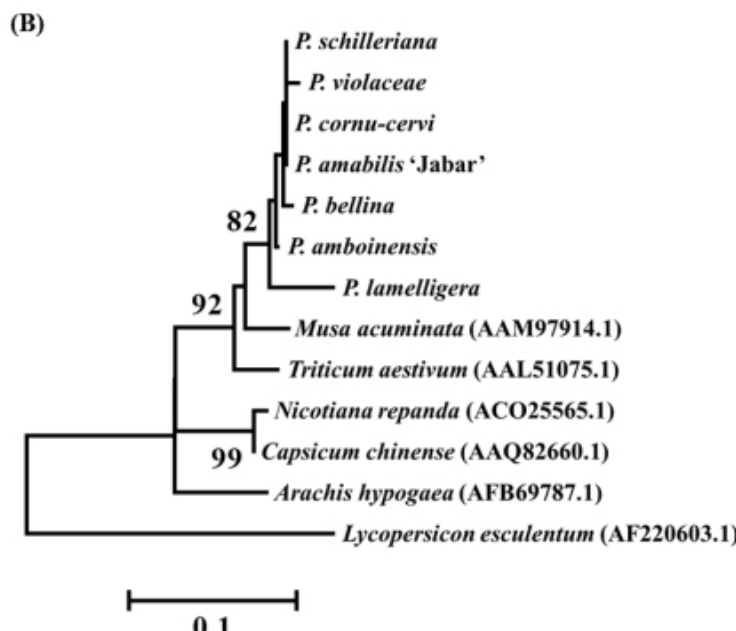

Gambar 3. Hasil analisis filogenetik menggunakan: (A) Runutan asam amino hasil translasi dari amplikon, dan (B) Runutan asam amino dari domain terkonservasi gen Pto, untuk 20 aksesi anggrek Phalaenopsis dan tanaman lain dengan metode Neighbor-Joining. Angka pada sumbu percabangan mununjukkan nilai hasil analisis bootstrap dengan 1000 ulangan

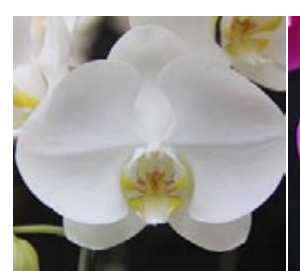

AMP17

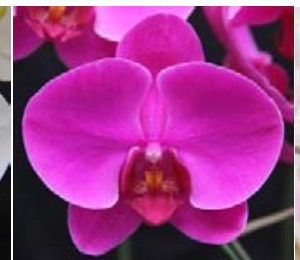

KHM0421

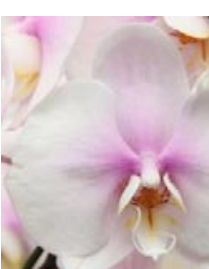

MKW002

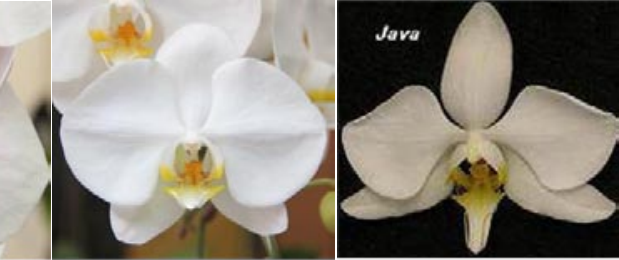

P. amabilis Jawa Barat

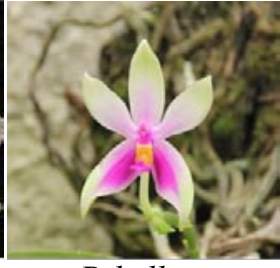

P. bellina
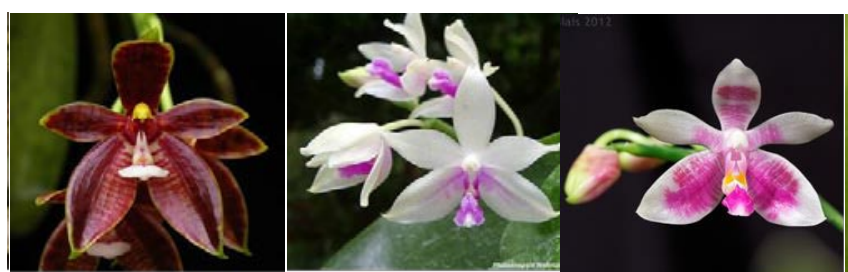

P. cornu-cervi

P. fimbriata

P. modesta

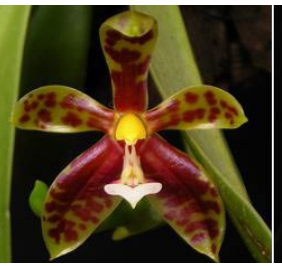

P. lamelligera
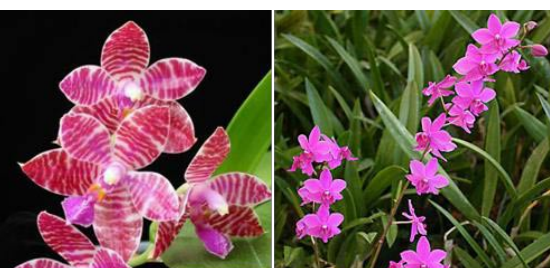

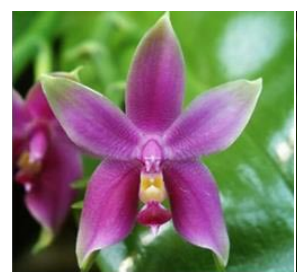

P. violaceae

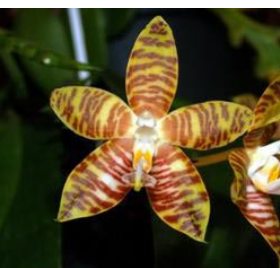

P. amboinensis

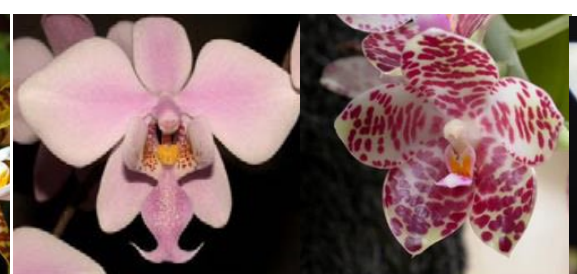

P. schilleriana

P. gigantea

$P$. lueddenmanniana

P. pulcherima

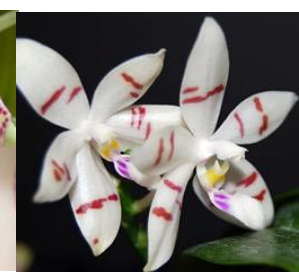

P. tetraspis

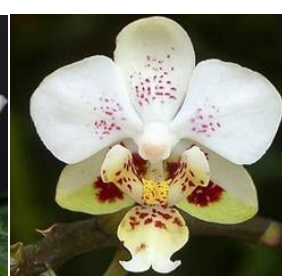

P. stuartiana

Gambar 4. Representasi keragaman karakteristik bunga dari berbagai aksesi anggrek Phalaenopsis yang digunakan dalam penelitian 


\section{KESIMPULAN}

PCR dengan pasangan primer PtoF dan PtoR serta templat genom Phalaenopsis menghasilkan amplikon sepanjang $\sim 500 \mathrm{pb}$, tetapi hasil DNA sequencing hanya mampu mengidentifikasi 449 pb. Amplikon asal Phalaenopsis menyandi 149 residu asam amino, yang kesamaan identitasnya mencapai $88 \%$ sampai $95 \%$ dengan sejumlah aksesi PTO di pangkalan data GenBank NCBI. Hasil analisis pensejajaran runutan asam amino menunjukkan bahwa amplikon merupakan penyandi bagian dari domain katalitik PTO dan domain serine threonine kinase sub famili Serine/Threonine kinases, Interleukin-1 Receptor Associated Kinases (STK_IRAK). Berdasarkan runutan asam aminonya, keragaman protein PTO antar genotipe Phalaenopsis tergolong rendah. Berdasarkan catalytic domain-nya, PTO asal Phalaenopsis diduga memiliki progenitor yang sama dengan PTO asal M. acuminata, T. aestivum, A. hypogaea, $C$. chinensis dan N. repanda tetapi berbeda dengan PTO asal tomat.

\section{UCAPAN TERIMA KASIH}

Penelitian ini merupakan bagian dari tesis magister Juanita Elina yang berjudul "Respon Ketahanan Inang terhadap Penyakit Busuk Lunak dan Karakterisasi Molekuler dengan Marka SNAP pada Anggrek Phalaenopsis." Penelitian didukung dana dari Hibah Kompetensi, No. Kontrak: 083/SP2H/PL/Dit.Litabmas/II/2015 tahun 2015, Ditjen Dikti, Kementerian Pendidikan Nasional RI, yang dikoordinir Dr Dewi Sukma.

\section{DAFTAR PUSTAKA}

Afzal, A.J., A.J. Wood, D.A. Lightfoot. 2008. Plant receptorlike serine threonine kinases: roles in signaling and plant defense. MPMI 21:507-517.

Castells, E., J.M. Casacuberta. 2007. Signalling through kinase-defective domain: the prevalance of atypical receptor-like kinases in plants. J. Exp. Bot. 58:35033511 .

Fu, S.F., H.J. Huang. 2011. Molecular characterization of the early response of orchid Phalaenopsis amabilis to Erwinia chrysanthemi infection. Orchid Biotech II:283-308.

Gurunani, M. A., J. Venkatesh, C. P. Upadhyaya, A. Nookaraju, S. K. Pandey, S. W. Park. 2012. Plant disease resistance genes: current status and future directions. Physiol. Molec. Plant Pathol. 78:51-65.

Handini, A.S. 2014. Analisis keragaman morfologi dan biokimia pada anggrek Phalaenopsis serta analisis keragaman genetik dengan marka SNAP. Tesis.
Sekolah Pascasarjana. Institut Pertanian Bogor. Bogor.

Han, X., L. Li, L. Cui, J. Xing, L. Tang, M. Cao. 2011. Isolation of candidate disease resistance genes from enrichment library of Oryza minuta based on conserved domains. African J. Biotechnol. 10:1473814745.

Kurniasih, S. 2012. Pemanfaatan marka molekuler untuk mendukung perakitan kultivar unggul kakao (Theobroma cacao L.). Disertasi. Sekolah Pascasarjana. Institut Pertanian Bogor. Bogor.

Lehti-Shiu, M.D., S. Shiu. 2012. Diversity, classification and function of the plant protein kinase superfamily. Phil. Trans. R. Soc. B. 367:2619-2639.

Marchler-Bauer, A., Y. Bo, L. Han, J. He, C.J. Lanczycki, S. Lu, F. Chitsaz, M.K.Derbyshire, R.C. Geer, N.R. Gonzales, M. Gwadz, D.I. Hurwitz, F. Lu, G.H.Marchler, J.S. Song, N. Thanki, Z. Wang, R.Z. Yamashita, D.Zhang, C.Zheng, L.Y.Geer, S.H. Bryant. 2017. CDD/SPARCLE: functional classification of proteins via subfamily domain architectures. Nucleic Acids Res. 45(D1):D200-D203.

Meyers, B.C., S. Kaushik, R.S. Nandety. 2005. Evolving disease resistance genes. Current Opinion Plant Biol. 8:129-134.

NCBI. 2003. Lycopersicon esculentum VFNT Cherry Pto locus, complete sequence. https://www.ncbi.nlm.nih. gov/nuccore/8547233/ [8 Agustus 2017].

Oh, C., G.B. Martin. 2011. Effector-triggered immunity mediated by the Pto kinase. Trends Plant Sci. 16:1360-1385.

Orsi, I., M. Malatrasi, E. Belfanti, M. Gulli, N. Marmiroli. 2011. Determining resistance to Pseudomonas syringae in tomato, a comparison of different molecular markers. Molec. Breeding 30:967-974.

Parravicini, G., C. Gessler, C. Denance, P. Lasserre-Zuber, E. Vergne, M. Brisset, A. Patocchi, C. Durel, G.A.L. Broggini. 2011. Identification of serine/threonine kinase and nucleotide-binding site-leucine-rich repeat (NBS-LRR) genes in the fire blight resistance quantitative trait locus of apple cultivar 'Evereste'. Molec. Plant Pathol. 12:493-505.

Peraza-Echeverria, S., A. James-Kay, B. Canto-Canche, E, Castillo-Castro. 2007. Structural and phylogenetic analysis of Pto-type disease resistance gene candidates in banana. Molec. Genet. Genomics 278:443-453. 
Quirin, E.A., H. Mann, R.S. Meyer, A. Traini, M.I. Chiusano, A. Litt, J.M. Bradeen. 2012. Evolutionary meta-analysis of solanaceous resistance gene and Solanum resistance gene analog sequences and a practical framework for cross-spesies comparisons. MPMI 25:603-612.

Rose, L.E., R.W. Michelmore, C.H. Langley. 2007. Natural variation in the Pto disease resistance gene within species of wild tomato (Lycopersicon). II. Population genetics of Pto. Genetics 175:1307-1319.

Singh, S.P., S. Vivek, R.L. Bezbaruah, M. Barooah. 2012. Prediction of the three-dimensional structure of serine/threonine protein kinase PTO of Solanum lycopersicumbyhomologymodelling. Bioinformation $8: 212-215$

Sudarsono, M.D. Haristianita, A.S. Handini, D. Sukma. 2017. Molecular marker development based on diversity of genes associated with pigment biosynthetic pathways to support breeding for novel colors in Phalaenopsis. Acta Hort. 1167:305-312.

Sudarsono, S., J. Elina, Giyanto, D. Sukma. 2017. Pathogen Causing Phalaenopsis Soft Rot Disease - 16S rDNA and Virulence Characterisation. Plant Protection Sci. http://www.agriculturejournals. cz/web/pps.htm?type=article\&id=18_2017-PPS. DOI:10.17221/18/2017-PPS.

Sukma, D., J. Elina, Giyanto, Sudarsono. 2017. Disease resistance breeding of Phalaenopsis spp. for tropical environment and molecular marker development for plant selection. Acta Hort. 1167:237-243.

Sutanto, A., D. Sukma, C. Hermanto, S. Sudarsono. 2014. Isolation and characterization of Resistance Gene Analogue (RGA) from Fusarium resistant banana cultivars. Emir. J. Food Agric. 26:508-518.
Tamura, K., D. Peterson, N. Peterson, G. Stecher, M. Nei, S. Kumar. 2011. MEGA5: molecular evolutionary genetics analysis using maximum likelihood, evolutionary distance, and maximum parsimony methods. Mol. Biol. Evol. 28:2731-2739.

Toth, I.K., J.M. van der Wolf, G. Saddler, E. Lojkowska, V. Helias, M. Pirhonen, L. Tsror (Lahkim), J.G. Elphinstone. 2011. Dickeya spesies: an emerging problem for potato production in Europe. Plant Pathol. 60:385-399.

Wan, H., C. Qian, A.A. Malik, Z. Zhao, J. Chen. 2009. Isolation, phylogeny and evolutionary analysis of Pto-type disease resistance gene analogues from a Cucumis hystrix introgression line of cucumber $(C$. sativus). Funct. Plant Biol. 37:513-523.

Wan, H., W. Yuan, M. Ruan, Q. Ye, R. Wang, Z. Li, G. Zhou, Z. Yao, Y. Yang. 2013. Identification, phylogeny, and expression analysis of Pto-like genes in pepper. Plant Molec. Biol. Rep. 31:901-916.

Yusnita, Y. W. Widodo, S. Sudarsono. 2005. In vitro selection of peanut somatic embryos on medium containing culture filtrate of Sclerotium rolfsii and plantlet regeneration. HAYATI J. Biosci. 12:50-56.

Zainal, A., A. Anwar, S. Ilyas, Sudarsono, Giyanto. 2011. Uji inokulasi dan respon ketahanan 38 genotipe tomat terhadap Clavibacter michiganensis subsp. michiganensis. J. Agron. Indonesia 39:85-91.

Zhai, W., Y. Zhao, L.X. Zhang, X.J. Li. 2014. Structural and phylogenetic analysis of Pto-type disease resistance gene candidates in Hevea brasiliensis. Genet. Molec. Res. 13:4348-4360. 